\title{
A Review of Airborne Particulate Matter Effects on Young Children's Respiratory Symptoms and Diseases
}

\author{
Hai-Ying Liu ${ }^{1, *}$, Daniel Dunea ${ }^{2, *(D)}$, Stefania Iordache ${ }^{2}$ and Alin Pohoata ${ }^{3}$ \\ 1 Department of Environmental Impacts and Sustainability, Norwegian Institute for Air Research, \\ Postboks 100, 2027 Kjeller, Norway \\ 2 Faculty of Environmental Engineering and Food Science, Valahia University of Targoviste, Aleea Sinaia \\ no.13, 130004 Targoviste, jud. Dambovita, Romania; stefania.iordache@yahoo.com \\ 3 Faculty of Sciences and Arts, Valahia University of Targoviste, Aleea Sinaia no.13, 130004 Targoviste, \\ jud. Dambovita, Romania; alinpohoata@yahoo.com \\ * Correspondence: hai-ying.liu@nilu.no (H.-Y.L.); dan.dunea@valahia.ro (D.D.); \\ Tel.: +47-6389-8048 (H.-Y.L.); +40-769-076-854 (D.D.)
}

Received: 12 March 2018; Accepted: 13 April 2018; Published: 16 April 2018

\begin{abstract}
Exposure to airborne fine particulate matter $\left(\mathrm{PM}_{2.5}\right)$ carries substantial health risks, particularly for younger children (0-10 years). Epidemiological evidence indicates that children are more susceptible to PM health effects than adults. We conducted a literature review to obtain an overview of existing knowledge regarding the correlation of exposure to short- and long-term PM concentrations with respiratory symptoms and disease in children. A collection of scientific papers and topical reviews were selected in cooperation with two experienced paediatricians. The literature review was performed using the keywords "air pollution", "particulate matter", "children's health" and "respiratory" from 1950 to 2016, searching the databases of Scopus, Google Scholar, Web of Science, and PubMed. The search provided 45,191 studies for consideration. Following the application of eligibility criteria and experts' best judgment to titles and abstracts, 28 independent studies were deemed relevant for further detailed review and knowledge extraction. The results showed that most studies focused mainly on the effect of short-term exposure in children, and the reported associations were relatively homogeneous amongst the studies. Most of the respiratory diseases observed in outdoor studies were related to changes in lung function and exacerbation of asthma symptoms. Allergic reactions were frequently reported in indoor studies. Asthma exacerbation, severe respiratory symptoms and moderate airway obstruction on spirometry were also observed in children due to various sources of indoor pollution in households and schools. Mixed indoor and outdoor studies indicate frequent occurrence of wheezing and deterioration of lung function. There is good evidence of the adverse effect of short-term exposure to PM on children's respiratory health. In terms of long-term exposure, fine particles $\left(\mathrm{PM}_{0.1}-\mathrm{PM}_{2.5}\right)$ represent a higher risk factor than coarse particles $\left(\mathrm{PM}_{2.5}-\mathrm{PM}_{10}\right)$. Additional research is required to better understand the heterogeneous sources and the association of PM and adverse children's health outcomes. We recommend long-term cooperation between air quality specialists, paediatricians, epidemiologists, and parents in order to improve the knowledge of PM effects on young children's respiratory health.
\end{abstract}

Keywords: air pollution; asthma; severe health effects; epidemiology; respiratory; wheezing

\section{Introduction}

Particulate matter (PM) has been shown to be one of the major airborne pollutants in urban environments, as it is comprised of inhalable particles that penetrate the thoracic region of the 
respiratory system, creating considerable adverse health effects [1-3]. Such health effects can be aggravated by individual vulnerability (e.g., children, elderly people, persons with chronic pulmonary and cardiopulmonary diseases, or with poor immune systems), and are dependent on exposure duration. It is well documented that exposure to high levels of PM causes major adverse health effects for those who live close to air pollution sources [4,5]. Results from the World Health Organization (WHO) [3] and other research studies [6-8] have indicated that exposure to PM results in respiratory morbidity (aggravation of asthma, respiratory symptoms and an increase in hospital admissions). Furthermore, excess mortality also results due to respiratory diseases and from lung cancer in adults $[9,10]$. Fine fractions of $\mathrm{PM}\left(\mathrm{PM}_{0.1}-\mathrm{PM}_{2.5}\right)$ induce cardiopulmonary disorders and/or impairments [11].

Children are not small adults [12] and are particularly vulnerable to exogenous factors such as air pollution. Their exposure to PM affects lung development, including irreversible deficits in lung function as well as chronically reduced lung growth rate [13-15]. Asthma is the most common chronic childhood disease and the leading cause of morbidity in chronic diseases in children [16]. Because of intensive urbanization, increased exposure to domestic allergens and growing levels of various air pollutants, the incidence of asthma in children has increased significantly in recent decades [17]. An important factor in asthma evolution is the removal of trigger factors [18]. In general, asthmatic children suffer limitation of daily physical activities, leading to school absenteeism. Multiple factors, including air pollution, are contributing to increased asthma morbidity. Recent studies performed in two Romanian cities indicated that the prevalence of asthma in children is increasing at a rate of $8-11 \%$ per year [19].

Safe levels of exposure, or a threshold below which no adverse health effects occur, are difficult to establish $[3,20,21]$. At present, research regarding the impact of different chemical species of PM on human health is carried out using a complex multidisciplinary approach [22,23]. Epidemiology studies [24-28] suggest that further research must focus on respirable dusts and their chemical speciation and should focus further on aggravated or causative effects in children up to 6 years as they are the most vulnerable $[19,29]$.

There is evidence that long-term reduced level of PM results both in health benefits $[5,30]$ and in reduced national health costs (e.g., diminishing of hospitalizations and associated treatment). Furthermore, quantitative knowledge of emission sources and levels, as well as trends in the emission of primary particles and precursor gases, plays an important role in finding the best control strategy for reducing risks at a spatiotemporal scale [31].

\subsection{What Is Particulate Matter and Where Does It Come From?}

The term PM is used for a mixture of solid particles and liquid droplets suspended in the air [32]. These particles originate from various sources such as combustion processes in road traffic and industry, vehicle braking, tire wear, pavement erosion, forest fires, chemical or photochemical reactions in the atmosphere, transport and dispersion of soil or rock particles from the soil surface, transport and dispersion of seawater droplets from surface of seas or oceans, volcanic eruptions, pollen dispersal, etc. [33].

PM in urban areas includes dust, dirt, soot, smoke, and liquid droplets emitted into the air mainly by vehicles, factories, residential heating and construction activities. PM inhalable, thoracic, and respirable fractions are pollutants of concern that act as major air quality stressors. Coarse particles are PM that exceeds 2.5 microns $(\mu \mathrm{m})$ in aerodynamic diameter up to $10 \mu \mathrm{m}\left(\mathrm{PM}_{10}\right)$, while fine particles are smaller than $2.5 \mu \mathrm{m}\left(\mathrm{PM}_{2.5}\right)$. Ultrafine particles have sizes up to 100 nanometres (nm) $\left(\mathrm{PM}_{0.1}\right)$.

\subsection{Chemical Composition of Particulate Matter and Its Potential Health Effects}

Through exposure to fine and coarse particles, and particularly to excessive levels of fine and coarse particles above the threshold limit values (Table 1), PM can penetrate into the thoracic regions or lower areas of the respiratory tract, causing asthma and respiratory morbidity. Studies indicate that 
fine particulates are the most important factor for adverse health effects, while coarse particulates have lower influence due to their relative large size [34]. Brown et al. (2013) [35] found that approximately $20 \%$ or less of $\mathrm{PM}_{10}$ particles penetrate through the extra thoracic airways and into the lower respiratory tract.

Table 1. Guideline values of exposure to $\mathrm{PM}_{2.5}$ and $\mathrm{PM}_{10}$ by World Health Organization (WHO 2011).

\begin{tabular}{cc}
\hline Guideline Values $\mathbf{P M}_{\mathbf{2 . 5}}$ & Guideline Values $\mathbf{P M}_{\mathbf{1 0}}$ \\
\hline $10 \mu \mathrm{g} / \mathrm{m}^{3}$ (annual mean) & $20 \mu \mathrm{g} / \mathrm{m}^{3}$ (annual mean) \\
$25 \mu \mathrm{g} / \mathrm{m}^{3}$ (24-h mean) & $50 \mu \mathrm{g} / \mathrm{m}^{3}$ (24-h mean) \\
\hline
\end{tabular}

Both chemical and physical compositions of PM depend on various factors, such as location, time of the year, and weather. Major components of PM include sulphate, nitrate, ammonium and hydrogen ions, trace elements (including toxic and transition metals), organic material, elemental carbon, and crustal components [36]. PM can also consist of at least 160 organic compounds and 20 metals (Ag, As, Ba, Be, Dc, Ce, Cr, Co, Cu, Fe, Mn, Nd, Ni, Pb, Sb, Se, Sr, Ti, V and Zn). Significant variations between polluted industry zones and background sites for each heavy metal concentration are observed in the analysed PM [37,38]. New environmental concerns are related to the presence of platinum group elements, or PGE, (Pt, $\mathrm{Pd}$ and $\mathrm{Rh}$ ) in airborne fine fraction of $\mathrm{PM}$ originating from automobile catalytic converters that employ these metals as exhaust catalysts. PGE have increased bioavailability because they may be solubilised by various compounds commonly present in the environment and transformed into more toxic species upon uptake by organisms. The presence of chloride in lung fluids may result in the formation of halogenated PGE complexes, which have an increased potential for inducing cellular damage [39].

The abundance of chemical species in PM has a seasonal dependency based on their volatility and the influence of photochemical production of secondary species [40]. Kim et al. (2015) [41] compared coarse and fine particles based on composition, common emission sources, life span, and travel distance reported in the literature. They observed that $\mathrm{PM}_{2.5}$ contains more hazardous chemical species such as Polycyclic Aromatic Hydrocarbons (PAHs) and heavy metals, which have carcinogenic, mutagenic and/or teratogenic effects [42]. Various health effects of $\mathrm{PM}_{2.5}$, ranging from insignificant to very serious, are associated with its specific chemical and physical components. While heavy metals have an influence on chronic disease development in correlation with exposure time and bioaccumulation mainly in adults [43], PAHs tend to be more dangerous to the health of children due to their direct toxic effect [44]. The US Environmental Protection Agency (EPA) and the EU European Environmental Agency (EEA) have identified a list of 16 priority PAHs for monitoring [45], from which Benzo(a)Pyrene (BaP) is in the first carcinogenic group. The complexity of PM chemical speciation reinforces the relevance of rigorous PM monitoring and associated micro-pollutants for reliable air quality management [46].

\subsection{Objective of the Study}

This paper presents the results of a quantitative meta-data-based literature review on existing knowledge of airborne PM's effects on young children's health. As such, this article aims to provide a snapshot on the progress and setbacks in PM research, focusing on the respiratory health effects in young children ( $0-10$ years) as one of the most vulnerable groups of society. We have selected this age interval based on the recommendations from paediatric specialists knowing that children under 10 years (infants, pre-schoolers and small schoolers) have a faster breathing rate, a peculiar immune system and an uncertain response to asthma controller medications for sensitive children compared to older age children. The automatic search using the selected "Air pollution—Particulate matter-Children's health-Respiratory" syntax followed by best judgment assessments using established criteria and professional experience provided a non-exhaustive basic list to be used as a roadmap with meaningful milestones for those new to the field. 


\section{Methodology}

Our review was based on a collection of scientific papers and topical reviews, selected in cooperation with two experienced paediatricians ( $>25$ years of praxis) from two emergency hospitals located in different cities. The literature was obtained by using a step-by-step search string in four of the most accessed databases (Scopus, Google Scholar, Web of Science, and PubMed), using the first keyword with subsequent ones in the following order: Air pollution-Particulate matter-Children's health-Respiratory. The search period was from 1950 to 2016.

The number of citations was used as prioritization criteria to facilitate the consultation of the results between 1950 and 2010. The number of citations for articles published between 2011 and 2016 was not considered as criteria for including or excluding. Because they have been published relatively recently, their number of citations might have been quite low. However, we reviewed the abstracts for articles published between 2011 and 2016. At the end, 28 selected articles were reviewed in full text (Figure 1).

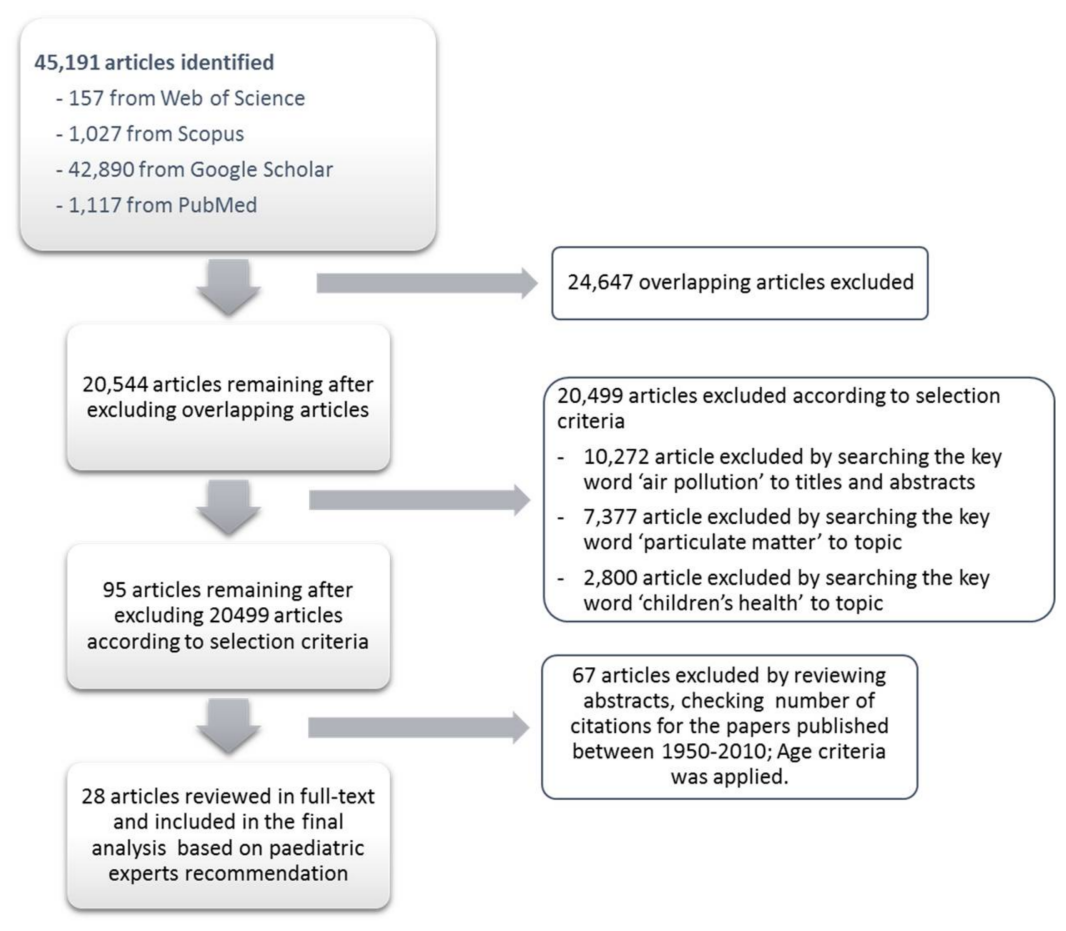

Figure 1. Selection process for articles' review and meta-analysis.

\section{Results}

\subsection{Databases' Automatic Search Results}

The results were grouped according to five time-periods (1950-1980, 1981-1990, 1991-2000, 2001-2010 and 2011-2016).

The number of studies on PM effects on children's health increased over the years, and reached their highest number around the year 2010. The early-published papers generally discussed the effects of smoking and indoor air quality on children's health (1950-2000). A consistent progress on this topic towards complex multidisciplinary approaches was observed in each database, especially in the last period (2011-2016). Such advanced studies involved PM monitoring, chemical speciation, spatiotemporal modelling, and source apportionment correlated with epidemiological surveys amongst children. 
Adding the keyword "respiratory" has significantly reduced the number of hits in all databases (Table S1, Figure S1), leading to 45,191 articles, which included 157 from Web of Science, 1027 from Scopus, 42,890 from Google Scholar and 1117 from PubMed (Table S1). Many articles have been indexed in all four databases. Of particular interest was the relatively low number of documents that discussed respiratory problems in children caused by PM, i.e., 2.4\% (PubMed), 4.4\% (Web of Science), 9.9\% (Google Scholar) and 15.3\% (Scopus).

After applying the eligibility criteria with the best judgment of paediatric experts, 28 independent studies were deemed relevant to build a basic list summarising the main respiratory health effects in young children (See Table S2). Out of these, 9 studies focused on outdoor, 8 on indoor, and 11 on indoor and outdoor environments. Most of the selected articles were published between 2011 and 2016 (22 articles) and in 2010 ( 4 articles). This showed that this topic is relatively new.

The following section presents a synthesis of our literature review, pointing out in brief the key research elements about the relationship of PM to respiratory health effects in children. Due to the numerous findings in various fields of this topic, the synthesis is presented following the DPSEEA (Driving forces, Pressures, State, Exposures, Health effects and Actions) framework [47,48], focussing mainly on novel approaches and future trends regarding the PM effects on children's respiratory health.

\subsection{Current Knowledge on the Effects of Particulate Matter on Children's Health}

\subsubsection{Growth and Development of Children in Relation to Exposure to Air Pollution}

Children are not "adults in miniature", because they are undergoing multiple transformations from newborn status to adolescence. This process of growth and development is dynamic, continuous and complex, comprising quantitative, biological and functional modifications.

The effect of the environment on children's health is not limited only to childhood, but starts from parental exposure before conception, maternal exposure during pregnancy and continues with the child's exposure in all stages of development from new-born to teenager [16]. Prenatal exposure to fine particles increases susceptibility to respiratory infections and determines respiratory morbidity in early childhood [49]. Furthermore, study found that prenatal $\mathrm{PM}_{2.5}$ exposure at mid-gestation is associated with asthma development by age 6 years in boys [50].

Children under 10 years have a faster breathing rate compared to adolescents and adults, which results in inhalation of higher quantities of air and, depending on its pollutant load, a more pronounced exposure [12,19]. Other indicators that should be considered for investigation are diurnal symptoms per week, nocturnal symptoms per month, response to $\beta 2$ (Short-acting bronchodilators) inhalation medication, serum levels of immunoglobulin $E$, eosinophil count, and the child's physical status and activities [51]. Functional exploration of the respiratory tract is important to establish the diagnostic, monitoring progress and the severity of chronic respiratory diseases that are potentially triggered from exposure to air pollutants [51,52].

The oxygen consumption of newborns is about $30 \mathrm{~mL} / \mathrm{min}$, approximately $150 \mathrm{~mL} / \mathrm{min}$ for a child of 10 years of age in basal conditions, and $3000 \mathrm{~mL} / \mathrm{min}$ can be reached for a teenager of 16 years under maximal effort [53]. These values indicate that child lungs must cope with significant variations regarding the requirements of gaseous exchange related to somatic growth and the child's activity. Investigation of pulmonary function can be achieved through a series of lung functional tests using various methods: spirometry, peak expiratory flow (PEF) measurements and plethysmography [54]. PEF readings provide an objective measure of how well the lungs are functioning and the maximum flow that can be produced during forced expiration. Thus, a decrease in PEF reveals that lung function has decreased. When asthma is controlled, PEF readings do not vary from day to day. Daily monitoring of PEF values allows for detection of lung function variability, and can even predict an asthma attack days before [55]. It also proves to be a useful method for highlighting the diurnal variation of PEF [56]. 
Children with obstructive lung disease associated with prolonged exposure to air pollutants have difficulty with expiration. Consequently, they tend to have an increased residual volume (RV), a decreased Vital Capacity (VC), and an almost normal Total Lung Capacity (TLC) [54-57].

Some averaged results reported in literature for outdoor $\mathrm{PM}_{2.5}$ estimated doses related to the children's weight were $0.2 \mu \mathrm{g} / \mathrm{kg} \cdot$ day [58], $0.32 \mu \mathrm{g} / \mathrm{kg} \cdot$ day [59] and $0.22-0.26 \mu \mathrm{g} / \mathrm{kg} \cdot$ day [19] for sensitive children with reduced PEF. Overall, changes in lung anatomy and breathing patterns associated with growth and development of children need to be critically considered when assessing PM exposure/dose [60].

\subsubsection{Effects of Exposure to Particulate Matter on the Pulmonary Function in Children}

Pulmonary Function and PM Impairment Mechanism

After birth, pulmonary development continues up to the age of 8 years in two stages: (i) the formation of new alveoli up to the age of 3 years (at birth, only 1/8 of the total adult alveoli are finalised); and (ii) the phase in which the pulmonary alveoli and other structures of the respiratory tract increase in volume. The reasons for higher impact on children's respiratory health compared to adults are due to the morpho-functional peculiarities of the respiratory system in children $[61,62]$. This includes (i) immaturity of the respiratory muscles; (ii) higher respiratory rate than adults, where children breathe more air relative to their body weight; the metabolic rate (reflected in $\mathrm{O}_{2}$ consumption and $\mathrm{CO}_{2}$ production) per body weight in children is higher than that in adults, which is reflected in higher minute ventilation (the product of tidal volume and breathing frequency) per body weight in children than in adults [60]; (iii) shorter airways than adults, so that the particles can reach the lung more easily; (iv) immaturity of the lung immune system, resulting in bronchial hyper-reactivity in contact with pollutants' allergens; (v) predominance of cholinergic system; (vi) $80 \%$ of alveoli are formed from birth up to the age of 6; and (vii) development of lung function during adolescence [63]. The lungs of children are continuously exposed to the external environment and are thus susceptible to many respiratory diseases [64]. The human respiratory system is able to filter out large particles, but is vulnerable to particles with diameters lower than $10 \mu \mathrm{m}$, in particular $\mathrm{PM}_{2.5}$ and $\mathrm{PM}_{0.1}$. In addition to particle diameter, the depth of penetration into the lungs depends on multiple factors as follows: age, physical effort, breathing type-oral/nasal, pre-existence of respiratory diseases, weather conditions, and the presence of other pollutants/aerosols into the surrounding air [65]. Obstruction of respiratory airways (asthma) causes changes in the lungs' normal size [66].

A majority of fine particles may deposit deep in the lungs because of reduced inertia when inhaled in slow, deep breaths. They penetrate deep into the acinus passing through the nasal and conducting airways without depositing. If there is vigorous mixing between the particle-laden tidal airflow and the alveolar residual air, and sufficient time for deposition, then a significant portion of the particles are likely to deposit in the acinus [67]. Children generally spend more time outdoors, which predisposes the lungs to a higher inhalation of air pollutants in areas with increased concentrations.

$\mathrm{PM}$ was found to trigger pulmonary oxidative stress and inflammation. When child airway epithelial cells are exposed to PM, inflammatory cytokines are produced. Alveolar macrophages exhibit respiratory burst activity, producing reactive oxygen species, nitrogen species, and release TNF- $\alpha$ (tumour necrosis factor) and IL-1 (interleukin 1) after exposure [68]. In addition to oxidative stress generated from activation of inflammatory cells, reactive oxygen species may be directly generated from the surface of particles [69]. This oxidative damage is associated with the primary development of asthma and chronic obstructive pulmonary disease (COPD). Exposure to $\mathrm{PM}_{2.5}$ may alter and impair normal immune responses of the lung concomitantly with other exogenous factors, making it susceptible to infections.

In the first step, $\mathrm{PM}_{2.5}$ can impair the bronchial mucociliary system and result in decrease of bacterial clearance [11]. In the second step, $\mathrm{PM}_{2.5}$ and $\mathrm{PM}_{2.5}$-induced disorder of inflammatory cytokines may trigger the death of lung epithelial cells and fibroblasts and inhibit the intercellular 
communication between these cells. This will increase the epithelial barrier permeability impairing their function as the physical barriers for pulmonary innate immunity [70].

Table S3 presents the most reported respiratory symptoms and diseases occurring in children that are potentially triggered and/or aggravated by air pollution especially from exposure to fine fractions of PM [71].

\section{Quantitative Effects of PM on Pulmonary Function}

In the U.S., a four-month study that measured the daily PEF at bedtime using peak flow meters was performed with children of 9 and 10 years of age [72]. A significant correlation was found between the measured values of $\mathrm{PM}_{10}$ and the average PEF variations. In the UK, Scarlett et al. [73] found a very small, but statistically significant, adverse effect of $\mathrm{PM}_{10}$ on lung function in a group of 154 children attending a primary school adjacent to a major motorway. A significant inverse relationship between daily mean $\mathrm{PM}_{10}$ levels lagged one day and Forced Vital Capacity (FVC) was observed with a reduction in lung function of $1 \%(95 \%$ CI $0.3 \%$ to $2 \%)$ across the whole range of $\mathrm{PM}_{10}$ levels (20-150 $\mu \mathrm{g} \mathrm{m}^{-3}$ ). In Austria, Neuberger and Moshammer (2004) [74] observed that the active surface of particles inhaled by children several hours to days before spirometry was related to short-term reductions in FVC, Forced Expiratory Volume in one second (FEV1) and Maximal Expiratory Flow rate at 50\% of vital capacity (MEF50). Four week-diaries indicated that the respiratory symptoms increased with acute exposure to a higher active surface of particles, such as wheezing, dyspnoea, coughing when going to sleep, and coughing at night in children with asthma or previous airways obstruction. In Japan, Watanabe et al. (2016) [75] investigated the effect of particulate air pollutants on respiratory symptoms and the inflammatory response in schoolchildren. Their results indicated that daily-suspended particulate matter (SPM) levels were not associated with respiratory symptoms or the daily amount of interleukin IL-6, IL-8, and tumour necrosis factor TNF- $\alpha$ level. Conversely, there was a significant association between respiratory symptoms and the daily IL-6, IL-8, and TNF- $\alpha$ level. These results suggest that the effects of particulate air pollutants on respiratory symptoms in schoolchildren might depend more on the pro-inflammatory response to them than on their mass concentration. These findings indicated that lung function declines immediately after a pronounced exposure to air pollution. A similar approach has been applied in numerous studies worldwide. The articles related to these studies show that the lung function of children had an acute and irreversible decrease after pollution episodes of ozone and PM [76-78]. However, in Finland, most regression coefficients between air pollution, including $\mathrm{PM}_{10}$ and morning and evening PEF, were negative but not statistically significant in 56 symptomatic children (34 with asthma and 16 with a dry cough) near a steel factory [79]. According to new research led by Rice et al. (2016) [80], improved air quality in U.S. cities since the 1990s may not be enough to ensure normal lung function in children, and even low levels of air pollution including $\mathrm{PM}_{2.5}$ and Black Carbon (BC) appear to affect children's respiratory health. From their study, lung function of children at the age of eight, living within 100 meters of a major roadway, was on average $6 \%$ lower than that of children living $400 \mathrm{~m}$ or more away [80]. Monitoring occurrences of wheezing in the absence of fever can provide a reliable assessment of the air pollution effect on the exacerbation of asthma and respiratory disorders in sensitive children [19].

Although not without inconsistencies, the existing wider body of research suggests that PM exposure can influence lung development and can have an important impact on lung function in children, both for those with and without pre-existing lung diseases. To address the variations that persist, large cohort studies with frequent comprehensive participant evaluations and individual level PM exposure assessments are needed [81]. However, studies on indoor air pollution have tended to be of small amplitude, making definitive conclusions more challenging [82]. These knowledge gaps indicate that further epidemiological studies are required and in addition, new methods of investigation should be developed. 
3.2.3. Effects of Exposure to Particulate Matter on Children's Health: Short- vs. Long-Term and Outdoor vs. Indoor

In the general population, secondary symptoms of exposure to PM are caused both by short-term (hours, days) and long-term exposure (months, years), and include: (i) respiratory morbidity, such as asthma worsening, respiratory symptoms, and increasing of hospital admissions [48,51,83]; and (ii) mortality through respiratory diseases or lung cancer, respectively $[9,10]$. In children, respiratory symptoms are divided into two main categories: symptoms related to diseases of the upper respiratory airways (cough, runny nose, sore throat and ear pain-otalgia) that are usually viral and treated at home with symptomatic medication (supportive care); and symptoms related to diseases of the lower respiratory airways (persistent cough, shortness of breath-dyspnoea, wheezing and chest pain). Those symptoms are much more serious and can be treated either through home supportive care or more frequently by hospital admission [57]. Table 2 summarises the main health effects recorded in the children's population in various countries of the world, which were reported in the articles we reviewed in full.

Table 2. Summary of particulate matter health effects on young children's respiratory symptoms and diseases extracted from selected articles based on eligibility criteria and best judgment of paediatric experts (more details in Table S2).

\begin{tabular}{|c|c|c|c|c|}
\hline Health Effects & Author & Country & $\begin{array}{l}\text { Location of } \\
\text { Study }\end{array}$ & $\begin{array}{c}\text { Number of } \\
\text { Children }\end{array}$ \\
\hline \multirow{6}{*}{$\begin{array}{l}\text { Respiratory symptoms and } \\
\text { inflammatory response } \\
\text { (shortness of breath, wet and } \\
\text { dry cough, wheezing, chest } \\
\text { tightness, throat congestion) }\end{array}$} & Kumar et al. (2007) [84] & India & Indoor \& outdoor & 394 \\
\hline & Siddique et al. (2010) [85] & India & Outdoor & 16,164 \\
\hline & Barakat-Haddad et al. (2012) [86] & Canada & Outdoor & 395 \\
\hline & Oluwole et al. (2013) [87] & Nigeria & Indoor & 59 \\
\hline & Nunes et al. (2015) [88] & Portugal & Indoor \& outdoor & $\mathrm{N} / \mathrm{A}$ \\
\hline & Watanabe et al. (2016) [75] & Japan & Indoor \& outdoor & 360 \\
\hline \multirow{3}{*}{$\begin{array}{l}\text { Wheezing and poor } \\
\text { respiratory health status }\end{array}$} & Rodriguez et al. (2010) [89] & Colombia & Indoor \& outdoor & 768 \\
\hline & Nandasena et al. (2012) [90] & Sri Lanka & Indoor \&outdoor & $\mathrm{N} / \mathrm{A}$ \\
\hline & Pedersen et al. (2013) [91] & Europe & Outdoor & $\mathrm{N} / \mathrm{A}$ \\
\hline \multirow{7}{*}{$\begin{array}{c}\text { Asthma, Asthma and } \\
\text { bronchiolitis, atopy and } \\
\text { airways inflammation, } \\
\text { Hospital admissions and } \\
\text { emergency department visits } \\
\text { for asthma }\end{array}$} & Gehring et al. (2010) [92] & Germany & Outdoor & 3863 \\
\hline & Butz et al. (2011a) [93] & USA & Indoor & 126 \\
\hline & Butz et al. (2011b) [94] & USA & Indoor & 41 \\
\hline & Robinson et al. (2011) [95] & Peru & Indoor & 1441 \\
\hline & Lewin et al. (2013) [96] & Canada & Outdoor & $\mathrm{N} / \mathrm{A}$ \\
\hline & Madureira et al. (2015) [97] & Portugal & Indoor & 1600 \\
\hline & Lim et al. (2016) [98] & Global & Indoor \& outdoor & $\mathrm{N} / \mathrm{A}$ \\
\hline \multirow{7}{*}{$\begin{array}{l}\text { Deterioration and changes of } \\
\text { lung function }\end{array}$} & He et al. (2010) [77] & China & Outdoor & 983 \\
\hline & Siddique et al. (2011) [99] & India & Indoor \& outdoor & 5671 \\
\hline & Zora et al. (2013) [100] & USA & Outdoor & $\mathrm{N} / \mathrm{A}$ \\
\hline & Buonanno et al. (2013) [101] & Italy & Indoor \& outdoor & 103 \\
\hline & Ferreira \& Cardoso (2014) [102] & Portugal & Indoor \& outdoor & 1019 \\
\hline & Paulin \& Hansel (2016) [82] & Global & Indoor \& outdoor & $\mathrm{N} / \mathrm{A}$ \\
\hline & Rice et al. (2016) [80] & USA & Indoor \& outdoor & 614 \\
\hline \multirow{2}{*}{$\begin{array}{c}\text { Acute lower respiratory tract } \\
\text { infections }\end{array}$} & Ramesh et al. (2012) [103] & India & Indoor & 202 \\
\hline & Sram et al. (2013) [104] & Czech Republic & Outdoor & 1492 \\
\hline $\begin{array}{c}\text { Increasing risk of } \\
\text { hospitalization for all } \\
\text { diagnoses }\end{array}$ & Marchettia et al. (2014) [105] & Italy & Outdoor & 3854 \\
\hline $\begin{array}{l}\text { Onset of skin, mucosal and } \\
\text { general symptoms }\end{array}$ & Zhang et al. (2014a) [106] & China & Indoor & 2134 \\
\hline
\end{tabular}

Most of the health effects observed in outdoor studies were related to a change in lung function [77, $85,86,104,105]$ and asthma symptoms exacerbation $[2,85,92,96,100]$.

In indoor studies, allergic reactions were frequently reported $[95,97,107]$. Atopy, which is an abnormal production of $\mathrm{E}$ immunoglobulin as a response to surrounding allergens, is the strongest predisposing factor for developing asthma. Asthma exacerbation [93,94], severe respiratory symptoms [84,108], acute lower respiratory tract infections [103] and moderate airway obstruction on spirometry [109] 
were also observed in children due to various sources of indoor pollution (e.g., smoking, stoves, allergens, etc.) in households [87] and schools [106]. The presence of various allergens (e.g., house dust, moulds, feathers, hair, fur, etc.) and chemical emissions (from furniture, carpets, repellents, scents, wall paintings, etc.) in indoor environments has a major effect acting as asthma triggers. In this context, PM fine fractions might have a secondary adverse contribution to children's respiratory health as well.

Mixed studies (indoor and outdoor) pointed out the frequent occurrence of wheezing $[88,89]$ as well as deterioration of lung function [88,102]. Buonanno et al. (2013) [101] found significant changes in pulmonary function tests using continuous exposure monitoring. Their study aimed to estimate alveolar and tracheobronchial dose, measured as deposited surface area for 103 children and to evaluate the long-term effects of exposure to ultrafine particles from traffic emission through spirometry, skin prick tests and measurement of exhaled nitric oxide (eNO). eNO is a relevant marker to the various clinical aspects of asthma in young children. It can be used as a predictor of asthma development in children with persistent respiratory manifestations (i.e., rhinitis, cough, wheezing) and is useful for monitoring patients treated with biological medication [110]. It may be used in the evaluation of one of the most common chronic/recurrent symptoms responsible for hospital admission of a child: the chronic cough [111].

Air pollution episodes are clearly a trigger for respiratory symptoms in sensitive children and children with asthma, which can become serious and even result in respiratory failure if not treated properly. These symptoms include a decrease of lung function, an increase of visits to emergency departments and hospitalizations, as well as an increase in severity of symptoms. In many situations, severe effects may occur despite the use of inhaled asthma medication [19].

Figure 2 illustrates the cause - effect relation in asthma, starting from various triggers including air pollution, to aggravating effects such as inflammation, hyperactivity and obstruction of the respiratory tract. If specific medication does not succeed in reducing the severity of symptoms, emergency room visits and/or hospital admission are required. Modifications of symptomatology may result from removal of pollutants or allergens/irritants around children, seasonal changes with variable exposure to pollen or dust, increase in viral infections during the cold months, and lung development together with child evolution influenced by the genetic susceptibility [112,113]. A comprehensive overview regarding the impact of early-life exposure to airborne environmental insults on the function of the airway epithelium in asthma can be found in Spann et al. (2016) [114].

An asthma attack is the result of an exacerbation of the oxidative stress from reactive oxygen species (ROS), manifested more frequently during the night or early morning, by the appearance of paroxysms with specific symptoms [72]. Lim et al. (2016) [98] carried out a study on the short-term effect of $\mathrm{PM}_{2.5}$ on children's hospital admissions and emergency department visits for asthma. Their primary meta-analysis indicated that hospital admissions and repeat emergency department visits for children with asthma were positively associated with a short-term $10 \mu \mathrm{g} / \mathrm{m}^{3}$ increase in $\mathrm{PM}_{2.5}$. In a longitudinal cohort study of children living in high-density New York City neighbourhoods, residential proximity and density of traffic and stationary sources of air pollution were associated with wheezing, reported asthma, and higher levels of total IgE between birth and 5 years of age [29].

These severe health effects are the reason that most countries have enforced preventative measures and standards (e.g., air quality guidelines, air quality standards, air quality plans, etc.) to limit emissions of air pollutants in urban areas. 


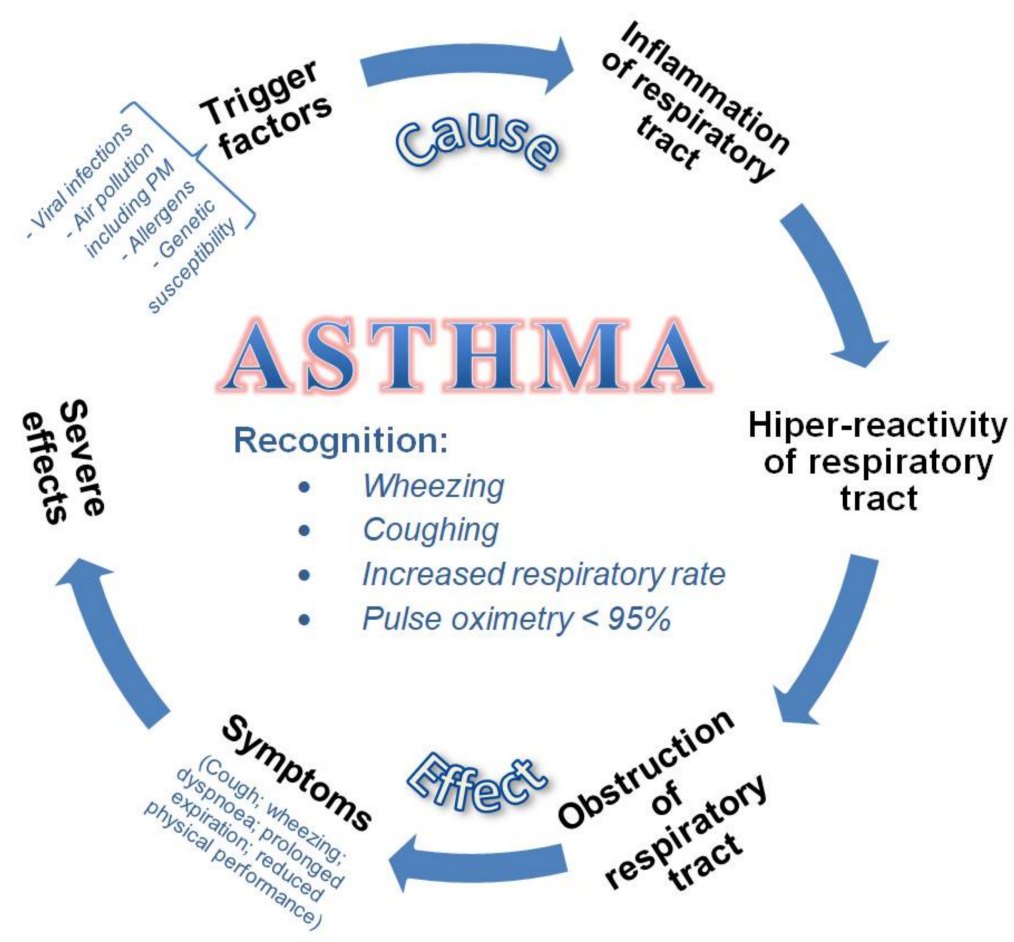

Figure 2. Causal relation between asthma in children and air pollution including airborne fine particulate matter from inflammation of respiratory tract (subclinical effects) to severe effects (Emergency Department visit; hospital admission; status asthmaticus; and premature mortality).

\section{Discussion}

Early lung function abnormalities lead to suboptimal respiratory function later in life [115] with major socioeconomic consequences. Continued exposure of children to airborne pollutants increases the severity of many lung diseases. In selected articles, the children exhibited the same respiratory health effects independent of location, economic status and PM concentrations levels of the country (Table 2). $\mathrm{PM}_{2.5}, \mathrm{PM}_{0.1}$ and soot may be a hazard to public health even at lower levels of exposure that are far below current national standards [80]. Combined with other air pollutants, PM has a significant negative synergic effect on children's normal lung functioning, especially within indoor microenvironments [97]. Unfortunately, there was no available information regarding the correlation between PM chemistry, particle morphology and associated respiratory health effects in the selected studies, which is another limitation of the current approach. However, it is difficult to find a direct link between individual chemical species and health effects, suggesting that a combination of chemical as well as physical properties of aerosols (mass, particle number, and surface area), contribute to adverse health effects [51,116].

The selected studies were homogeneous regarding the occurrence of respiratory health effects in indoor, outdoor and mixed exposure to PM pollutants. Differences in reports were observed between urban and rural areas. Some studies reported that rural areas may have more severe cases of respiratory symptoms and diseases $[88,108]$ that may result from parents waiting up to the point when a hospital visit is inevitable. Rural children were less likely to use asthma medications compared to children in urban areas [117], indicating a lack of asthma and respiratory symptoms control among rural children, resulting in more extreme health outcomes. Moreover, children in urban areas have more health resources to help control respiratory diseases and quicker ambulance response times.

Many reports showed that children in urban areas were more affected by PM exposure mainly because of the higher concentrations existing both indoor and outdoor, originating from nearby sources (e.g., traffic, industrial, heating, cooking, etc.). In the framework of European Study of Cohorts for 
Air Pollution Effects (ESCAPE) project, it was found that estimated levels of $\mathrm{PM}_{2.5}$ absorbance, and $\mathrm{PM}_{2.5}$ at the current address, but not at the birth address, were associated with small decreases in lung function based on data regarding the lung function at 6-8 years of age from birth cohort studies situated in Germany, Sweden, the Netherlands, and the United Kingdom [118,119].

Overall, the severity of respiratory health effects increasing the risk of hospitalization for all diagnoses was preponderantly determined by the child's age and sensitivity, degree of exposure to PM and other air pollutants, and association with viral infections.

In conclusion, Figure 3 summarises the main findings and facts related to the causality of respiratory health effects determined by PM exposure in young children.

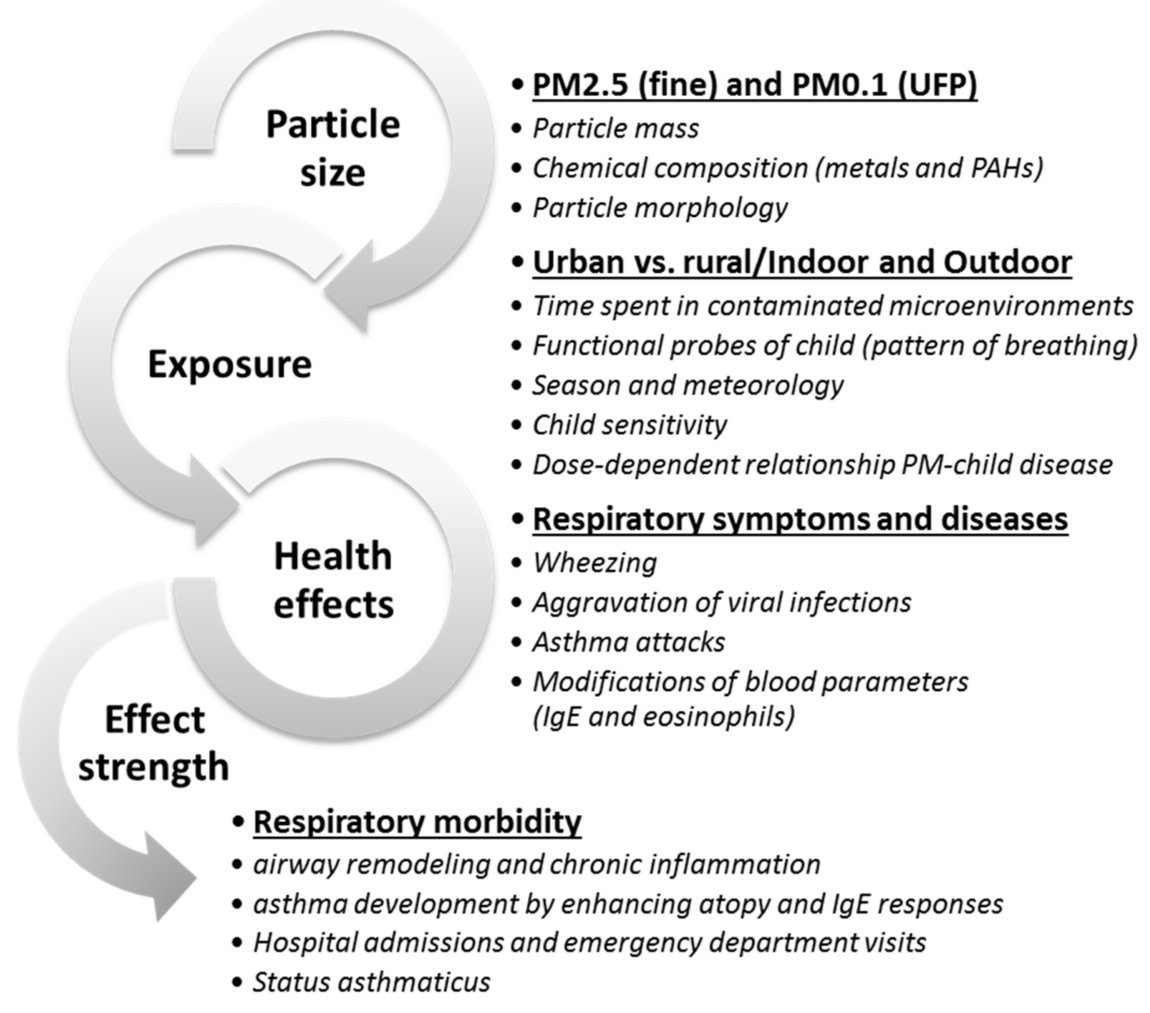

Figure 3. Synthetic representation of the main key points resulted from the literature review.

There is clear evidence that the decrease of air pollution levels due to interventions within air quality planning provides health benefits. These benefits are correlated with any decrease in the level of PM. With regard to the planning of living environments for vulnerable groups, the responsible authorities must ensure an optimal management of air quality through rigorous planning of public health, transport, construction and energy production according to local topography and meteorology.

\section{Conclusions}

In this review, we aimed to get an overview of the main respiratory effects for young children's exposure to PM by using the keywords "air pollution", "particulate matter", "children's health" and "respiratory". Due to use of keywords, our review of the extended literature may be limited in scope; Alternative keywords (e.g., "particulate air pollutants", "children", and "respiratory diseases") and synonyms could possibly have resulted in additional articles. Nevertheless, the initial search was used as a starting point, since many of the articles we read pointed us to additional studies.

From the present review, we can conclude that there is good evidence of the adverse effects of exposure of PM on young children's respiratory health. Exposure to PM affects lung development in children, including irreversible deficits in lung function as well as chronically reduced lung growth 
rate and a deficit in long-term lung function. There is no evidence of a safe level for PM exposure or a threshold below which no adverse health effects may occur. The exposure is ubiquitous and involuntary, increasing the significance of this health determinant. The relationship between particulate air pollutants and respiratory symptoms in children has not been consistent among studies, potentially owing to differences in the inflammatory response to different particulate air pollutants. The most frequently cited health effect among children living in areas with high concentrations of air pollutants was hospital admission due to respiratory symptoms, including wheezing, asthma and pneumonia.

The latest evidence indicates that not only the mass of PM, but also the number and size of the particles as well as chemical composition are influencing respiratory diseases, especially in young children. In this context, the development of dedicated prevention and research programs represents priority actions at the national to international level. Such programs must track the evolution of these patients in a broader collaboration, and include national and international specialised institutions, associations of patients (e.g., European Federation of Allergy and Airways Diseases Patients' Associations), and most importantly, the parents. Furthermore, parents can provide key information for future air quality studies by completing specific questionnaires, observing the child's status and development, and providing information about living conditions and socio-demographic characteristics. They should be integrated as active parts in air pollution-related epidemiological studies because they are first to observe the effects of air pollution episodes on children's respiratory health.

City authorities must focus on finding solutions to reduce emissions, monitor and forecast the levels of air pollutants and provide timely warning to at-risk populations when necessary. Refined information regarding air quality in urban environments, adapted to the level of a citizen's understanding, is valuable for vulnerable population groups, such as senior citizens, asthmatics and sensitive children, who can avoid certain PM affected areas with sufficient warning.

Supplementary Materials: The following are available online at http://www.mdpi.com/2073-4433/9/4/ 150/s1. Figure S1: The number of search results for each selected database using the search query "Air pollution-Particulate matter-Children's health-Respiratory" for five time intervals between 1950 and 2016. Table S1: Results of databases consultation (number of hits) using "AND" operator with subsequent keywords, grouped by various time intervals. Table S2: Summary of selected studies based on eligibility criteria and best judgment of paediatric experts on the effects of particulate matter on children's respiratory disease (non-exhaustive list). Table S3: Diagnoses potentially determined or aggravated by the atmospheric pollution classified according to the International Classification of Diseases ICD-10.

Acknowledgments: The research leading to these results has received funding from European Economic Area (EEA) Financial Mechanism 2009-2014 under the project ROKIDAIR “Towards a better protection of children against air pollution threats in the urban areas of Romania" with contract No. 20SEE/30.06.2014 (http:// www.rokidair.ro/en). The authors want to thank Mihaela Pohoata from the Emergency Hospital of Targoviste (Paediatrics), Cristina Buzatoiu from the Pediatric Hospital of Ploiesti and Marioara Stefana, paediatric doctor, for assistance with medical aspects related to respiratory health in children. The early version of this manuscript benefited from the suggestions and comments from Sonja Grossberndt. Special thanks to Mike Kobernus and Rebecca Jayne Thorne from NILU for the English language proofing and to three anonymous reviewers of Atmosphere whose pertinent comments significantly improved the manuscript.

Author Contributions: Hai-Ying Liu and Daniel Dunea designed the review methodologies, did literature review, analysed the review results and wrote the manuscript. Stefania Iordache and Alin Pohoata contributed to the literature review and manuscript writing.

Conflicts of Interest: The authors declare no conflict of interests. The funding sponsors had no role in the design of the study; in the collection, analyses or interpretation of data; in the writing of the manuscript; nor in the decision to publish the results.

\section{References}

1. Kampa, M.; Castanas, E. Human health effects of air pollution. Environ. Pollut. 2007, 151, 362-367. [CrossRef] [PubMed]

2. Liu, H.-Y.; Bartonova, A.; Schindler, M.; Sharma, M.; Behera, S.N.; Katiyar, K.; Dikshit, O. Respiratory disease in relation to outdoor air pollution in Kanpur, India. Arch. Environ. Occup. Health 2013, 68, $204-217$. [CrossRef] [PubMed] 
3. Health Effects of Particulate Matter-Policy Implications for Countries in Eastern Europe, Caucasus and Central Asia. Available online: http:/ / www.euro.who.int/_data/assets/pdf_file/0006/189051/Healtheffects-of-particulate-matter-final-Eng.pdf (accessed on 24 April 2017).

4. Moshammer, H.; Bartonova, A.; Hanke, W.; van den Hazel, P.; Koppe, J.G.; Krämer, U.; Ronchetti, R.; Sram, R.J.; Wallis, M.; Wallner, P.; et al. Air pollution: A threat to the health of our children. ACTA Paediatr. 2006, 95 (Suppl. S453), 93-105. [CrossRef] [PubMed]

5. Henschel, S.; Atkinson, R.; Zeka, A.; Le Tertre, A.; Analitis, A.; Katsouyanni, K.; Chanel, O.; Pascal, M.; Forsberg, B.; Medina, S.; et al. Air pollution interventions and their impact on public health. Int. J. Public Health 2012, 57, 757-768. [CrossRef] [PubMed]

6. Beelen, R.; Hoek, G.; van den Brandt, P.A.; Goldbohm, R.A.; Fischer, P.; Schouten, L.J.; Jerrett, M.; Hughes, E.; Armstrong, B.; Brunekreef, B. Long-term effects of traffic-related air pollution on mortality in a Dutch cohort (NLCS-AIR Study). Environ. Health Perspect. 2008, 116, 196-202. [CrossRef] [PubMed]

7. Samoli, E.; Peng, R.; Ramsay, T.; Pipikou, M.; Touloumi, G.; Dominici, F.; Burnett, R.; Cohen, A.; Krewski, D.; Samet, J.; et al. Acute effects of ambient particulate matter on mortality in Europe and North America: Results from the APHENA Study. Environ. Health Perspect. 2008, 116, 1480-1486. [CrossRef] [PubMed]

8. Extended Follow-Up and Spatial Analysis of the American Cancer Society Linking Particulate Air Pollution and Mortality Boston. Available online: http:/ / www.healtheffects.org/Pubs/RR140-Krewski.pdf (accessed on 23 April 2017).

9. Pope, C.A., III; Burnett, R.T.; Turner, M.C.; Cohen, A.; Krewski, D.; Jerrett, M.; Gapstur, S.M.; Thun, M.J. Lung Cancer and Cardiovascular Disease Mortality Associated with Ambient Air Pollution and Cigarette Smoke: Shape of the Exposure-Response Relationships. Environ. Health Perspect. 2011, 119, 1616-1621. [CrossRef] [PubMed]

10. Ambient (Outdoor) Air Quality and Health-Fact Sheet. Available online: http://www.who.int/ mediacentre/factsheets/fs313/en (accessed on 16 February 2017).

11. Feng, S.; Gao, D.; Liao, F.; Zhou, F.; Wang, X. The health effects of ambient $\mathrm{PM}_{2.5}$ and potential mechanisms. Ecotox. Environ. Safe 2016, 128, 67-74. [CrossRef] [PubMed]

12. Children are Not Little Adults. Available online: http://www.who.int/ceh/capacity/Children_are_not_ little_adults.pdf (accessed on 10 January 2017).

13. Briggs, D. Environmental pollution and the global burden of disease. Br. Med. Bull. 2003, 68, 1-24. [CrossRef] [PubMed]

14. Stanek, L.W.; Sacks, J.D.; Dutton, S.J.; Dubois, J.J.B. Attributing health effects to apportioned components and sources of particulate: An evaluation of collective results. Atmos. Environ. 2011, 45, 5655-5663. [CrossRef]

15. Brauer, M.; Amann, M.; Burnett, R.T.; Cohen, A.; Dentener, F.; Ezzati, M.; Henderson, S.B.; Krzyzanowski, M.; Martin, R.V.; Van Dingenen, R.; et al. Thurston GD. Exposure assessment for estimation of the global burden of disease attributable to outdoor air pollution. Environ. Sci. Technol. 2012, 46, 652-660. [CrossRef] [PubMed]

16. Kliegman, R.; Stanton, B.; St. Geme, J.; Schor, N. Nelson textbook of Pediatrics, 20th ed.; Elsevier: Philadelphia, PA, USA, 2016; pp. 1-3888. ISBN 9781455775668.

17. Gasana, J.; Dilikar, D.; Mendy, A.; Forno, E.; Ramos-Vieira, E. Motor vehicle air pollution and asthma in children: A meta-analysis. Environ. Res. 2012, 117, 36-45. [CrossRef] [PubMed]

18. Simpson, C.; Sheikh, A. Trends in the epidemiology of asthma in England: A national study of 333, 294 patients. J. R. Soc. Med. 2010, 103, 98-106. [CrossRef] [PubMed]

19. Dunea, D.; Iordache, S.; Pohoata, A. Fine particulate matter in urban environments: A trigger of respiratory symptoms in sensitive children. Int. J. Environ. Res. Public Health 2016, 13, 1246. [CrossRef] [PubMed]

20. Dusseldorp, A.; Kruize, H.; Brunekreef, B.; Hofschreuder, P.; de Meer, G.; van Oudvorst, A.B. Associations of $\mathrm{PM}_{10}$ and airborne iron with respiratory health of adults near a steel factory. Am. J. Respir. Crit. Care 1995, 152, 1932-1939. [CrossRef] [PubMed]

21. Quantitative Health Risk Assessment for Particulate Matter. Available online: https:/ /www3.epa.gov/ttn/ naaqs/standards/pm/data/PM_RA_FINAL_June_2010.pdf (accessed on 12 March 2018).

22. Harrison, R.M.; Jones, A.M.; Lawrence, R.G. Major component composition of $\mathrm{PM}_{10}$ and $\mathrm{PM}_{2.5}$ from roadside and urban background sites. Atmos. Environ. 2004, 38, 4531-4538. [CrossRef]

23. Iordache, S.; Dunea, D. Methods for the Assessment of Air Pollution with Particulate Matter to Children's Health (in Romanian with English Abstracts), 1st ed.; Matrix Rom: Bucharest, Romania, 2014; ISBN 978-606-25-0121-1. 
24. Ostro, B.D.; Rothschild, S. Air pollution and acute respiratory morbidity: An observational study of multiple pollutants. Environ. Res. 1989, 50, 238-247. [CrossRef]

25. Hiltermann, T.J.; Stolk, J.; van der Zee, S.C.; Brunekreef, B.; de Bruijne, C.R.; Fischer, P.H.; Ameling, C.B.; Sterk, P.J.; Hiemstra, P.S.; van Bree, L. Asthma severity and susceptibility to air pollution. Eur. Respir. J. 1998, 11, 686-693. [PubMed]

26. Roemer, W.; Hoek, G.; Brunekreef, B. Pollution effects on asthmatic children in Europe: The PEACE study. Clin. Exp. Allergy 2000, 30, 1067-1075. [CrossRef] [PubMed]

27. Hajat, S.; Anderson, H.; Atkinson, R.; Haines, A.; Seaton, A. Effects of air pollution on general practitioner consultations for upper respiratory diseases in London. Occup. Environ. Med. 2002, 59, 294-299. [CrossRef] [PubMed]

28. Dhondt, S.; Beckx, C.; Degraeuwe, B.; Lefebvre, W.; Kochan, B.; Bellemans, T.; Panis, L.I.; Macharis, C.; Putman, K. Health impact assessment of air pollution using a dynamic exposure profile: Implications for exposure and health impact estimates. Environ. Impact Assess. 2012, 36, 42-51. [CrossRef]

29. Patel, M.M.; Quinn, J.W.; Jung, K.H.; Hoepner, L.; Diaz, D.; Perzanowski, M.; Rundle, A.; Kinney, P.L.; Perera, F.P.; Miller, R.L. Traffic density and stationary sources of air pollution associated with wheeze, asthma, and immunoglobulin E from birth to age 5 years among New York City children. Environ. Res. 2011, 111, 1222-1229. [CrossRef] [PubMed]

30. Pope, C.A., III; Dockery, D.W. Health effects of fine particulate air pollution: Lines that connect. J. Air Waste Manag. Assoc. 2006, 56, 709-742. [CrossRef] [PubMed]

31. Fine Particulate Matter $\left(\mathrm{PM}_{2.5}\right)$ in the United Kingdom. Available online: https://www.gov.uk/government/ uploads/system/uploads/attachment_data/file/69635/pb13837-aqeg-fine-particle-matter-20121220.pdf (accessed on 12 March 2018).

32. Seinfeld, J.; Pandis, S. Atmospheric Chemistry and Physics: From Air Pollution to Climate Change, 2nd ed.; John Wiley \& Sons, Inc.: Hoboken, NJ, USA, 1998; p. 97. ISBN 0-471-17816-0.

33. Omidvarborna, H.; Kumar, A.; Kim, D.-S. Recent studies on soot modeling for diesel combustion. Renew. Sustain. Energy Rev. 2015, 48, 635-647. [CrossRef]

34. Chereminisoff, N.P. Handbook of Air Pollution Prevention and Control, 1st ed.; Butterworth-Heinemann: Oxford, UK, 2002; pp. 1-477.

35. Brown, J.S.; Gordon, T.; Price, O.; Asgharian, B. Thoracic and respirable particle definitions for human health risk assessment. Part Fibre Toxicol. 2013, 10, 12. [CrossRef] [PubMed]

36. Quality Assurance Project Plan for Pittsburgh Air Quality Study (PAQS). Available online: https://www3. epa.gov/ttnamti1/files/ambient/super/pittqapp.pdf (accessed on 16 February 2017).

37. Guideline on Speciated Particulate Monitoring. Available online: https://www3.epa.gov/ttnamti1/files/ ambient/pm25/spec/drispec.pdf (accessed on 12 March 2018).

38. Dai, Q.-L.; Bi, X.-H.; Wu, J.-H.; Zhang, Y.-F.; Wang, J.; Xu, H.; Yao, L.; Jiao, L.; Feng, Y.-C. Characterization and source identification of heavy metals on ambient $\mathrm{PM}_{10}$ and $\mathrm{PM}_{2.5}$ in an integrated iron and steel industry zone compared with a background site. Aerosol. Air Qual. Res. 2015, 15, 875-887. [CrossRef]

39. Wiseman, C.L.S.; Zereini, F. Airborne particulate matter, platinum group elements and human health: A review of recent evidence. Sci. Total Environ. 2009, 407, 2493-2500. [CrossRef] [PubMed]

40. Davidson, C.I.; Phalen, R.F.; Solomon, P.A. Airborne Particulate Matter and Human Health: A Review. Aerosol. Sci. Technol. 2005, 39, 737-749. [CrossRef]

41. Kim, K.-H.; Kabir, E.; Kabir, S. A review on the human health impact of airborne particulate matter. Environ. Int. 2015, 74, 136-143. [CrossRef] [PubMed]

42. Pedersen, M.; Vinzents, P.; Petersen, J.H.; Kleinjans, J.C.; Plas, G.; Kirsch-Volders, M.; Dostál, M.; Rössner, P.; Beskid, O.; Sram, R.J.; et al. Cytogenetic effects in children and mothers exposed to air pollution assessed by the frequency of micronuclei and fluorescence in situ hybridization (FISH): A family pilot study in the Czech Republic. Mutat. Res. 2006, 608, 112-120. [CrossRef] [PubMed]

43. Jaishankar, M.; Tseten, T.; Anbalagan, N.; Mathew, B.B.; Beeregowda, K.N. Toxicity, mechanism and health effects of some heavy metals. Interdiscip. Toxicol. 2014, 7, 60-72. [CrossRef] [PubMed]

44. Abdel-Shafy, H.I.; Mansour, M.S.M. A review on polycyclic aromatic hydrocarbons: Source, environmental impact, effect on human health and remediation. Egypt. J. Pet. 2016, 25, 107-123. [CrossRef] 
45. Amodio, M.; Andriani, E.; de Gennaro, G.; Di Gilio, A.; Ielpo, P.; Placentino, C.M.; Tutino, M. How a steel plant affects air quality of a nearby urban area: A study on metals and PAH concentrations. Aerosol. Air Qual. Res. 2013, 13, 497-508. [CrossRef]

46. Dunea, D.; Pohoata, A.; Iordache, S. Using wavelet-feedforward neural networks to improve air pollution forecasting in urban environments. Environ. Monit. Assess. 2015, 187, 477. [CrossRef] [PubMed]

47. Development of Environment and Health Indicators for European Union countries: Results of a Pilot Study. Available online: http:/ / apps.who.int/iris/bitstream/10665/107620/1/E85061.pdf (accessed on 12 March 2018).

48. Liu, H.-Y.; Bartonova, A.; Pascal, M.; Smolders, R.; Skjetne, E.; Dusinska, M. Approaches to integrated monitoring for environment and health impact assessment. Environ. Health 2012, 11, 88. [CrossRef] [PubMed]

49. Jedrychowski, W.A.; Perera, F.P.; Spengler, J.D.; Mroz, E.; Stigter, L.; Flak, E.; Majewska, R.; Klimaszewska-Rembiasz, M.; Jacek, R. Intrauterine exposure to fine particulate matter as a risk factor for increased susceptibility to acute broncho-pulmonary infections in early childhood. Int. J. Hyg. Environ. Health 2013, 216, 395-401. [CrossRef] [PubMed]

50. Hsu, H.H.; Chiu, Y.H.; Coull, B.A.; Kloog, I.; Schwartz, J.; Lee, A.; Wright, R.O.; Wright, R.J. Prenatal Particulate Air Pollution and Asthma Onset in Urban Children. Identifying Sensitive Windows and Sex Differences. Am. J. Respir. Crit. Care Med. 2015, 192, 1052-1059. [PubMed]

51. Dunea, D.; Iordache, S.; Liu, H.-Y.; Bøhler, T.; Pohoata, A.; Radulescu, C. Quantifying the impact of $\mathrm{PM}_{2.5}$ and associated heavy metals on respiratory health of children near metallurgical facilities. Environ. Sci. Pollut. Res. 2016, 23, 15395-15406. [CrossRef] [PubMed]

52. Athanazio, R. Airway disease: Similarities and differences between asthma, COPD and bronchiectasis. Clinics 2012, 67, 1335-1343. [CrossRef]

53. Popescu, V. Pathology of Respiratory System in Children (In Romanian); Teora: Bucharest, Romania, 1999.

54. Moshammer, H.; Neuberger, M. The active surface of suspended particles as a predictor of lung function and pulmonary symptoms in Austrian school children. Atmos. Environ. 2003, 37, 1737-1744. [CrossRef]

55. Thamrin, C.; Taylor, D.R.; Jones, S.L.; Suki, B.; Frey, U. Variability of lung function predicts loss of asthma control following withdrawal of inhaled corticosteroid treatment Free. Asthma 2010, 65, 403-408.

56. Noonan, C.W.; Ward, T.J. Asthma randomized trial of indoor wood smoke (ARTIS): Rationale and methods. Contemp. Clin. Trials 2012, 33, 1080-1087. [CrossRef] [PubMed]

57. Pohoata, M.; Buzatoiu, C. Current knowledge regarding the problems generated by the particulate matters on children's health. In Methods for the Assessment of Air Pollution with Particulate Matter to Children's Health; Iordache, Ş., Dunea, D., Eds.; Matrix Rom: Bucharest, Romania, 2014; pp. 267-290. ISBN 978-606-25-0121-1.

58. Greene, N.A.; Morris, V.R. Assessment of public health risks associated with atmospheric exposure to $\mathrm{PM}_{2.5}$ in Washington, DC, USA. Int. J. Environ. Res. Public Health 2006, 3, 86-97. [CrossRef] [PubMed]

59. Alves de Oliveira, B.F.; Ignotti, E.; Artaxo, P.; Hilário do Nascimento Saldiva, P.; Leite Junger, W.; Hacon, S. Risk assessment of $\mathrm{PM}_{2.5}$ to child residents in Brazilian Amazon region with biofuel production. Environ. Health 2012, 11, 64. [CrossRef] [PubMed]

60. Tsuda, A.; Henry, F.S.; Butler, J.P. Particle transport and deposition: Basic physics of particle kinetics. Compr. Physiol. 2013, 3, 1437-1471. [PubMed]

61. Gauderman, W.J.; Avol, E.; Gilliland, F.; Vora, H.; Thomas, D.; Berhane, K.; McConnell, R.; Kuenzli, N.; Lurmann, F.; Rappaport, E.; et al. The Effect of Air Pollution on Lung Development from 10 to 18 Years of Age. N. Engl. J. Med. 2004, 351, 1057-1067. [CrossRef] [PubMed]

62. Miller, M.D.; Marty, M.A. Impact of Environmental Chemicals on Lung Development. Environ. Health Perspect. 2010, 118, 1155-1164. [CrossRef] [PubMed]

63. Gauderman, W.J.; Urman, R.; Avol, E.; Berhane, K.; McConnell, R.; Rappaport, E.; Chang, R.; Lurmann, F.; Gilliland, F. Association of Improved Air Quality with Lung Development in Children. N. Engl. J. Med. 2015, 372, 905-913. [CrossRef] [PubMed]

64. La Grutta, S.; Indinnimeo, L.; Di Coste, A.; Ferrante, G.; Landi, M.; Pelosi, U.; Rusconi, F. Environmental risk factors and lung diseases in children: From guidelines to health effects. Early Hum. Dev. 2013, 89 (Suppl. S3), S59-S62. [CrossRef] [PubMed]

65. Battistini, A.; Marvasi, R. Inquinamento extradomiciliare e malattie respiratorie del bambino-Air pollution and lung diseases. Med. Bambino 2005, 24, 240-245. 
66. Tulic, M.K.; Christodoulopoulos, P.; Hamid, Q. Small airway inflammation in asthma. Respir. Res. 2001, 2, 333. [CrossRef] [PubMed]

67. Brain, J.D.; Valberg, P.A. Deposition of aerosol in the respiratory tract. Am. Rev. Respir. Dis. 1979, 120, 1325-1373. [PubMed]

68. Anderson, J.O.; Thundiyil, J.G.; Stolbach, A. Clearing the Air: A Review of the Effects of Particulate Matter Air Pollution on Human Health. J. Med. Toxicol. 2012, 8, 166-175. [CrossRef] [PubMed]

69. Risom, L.; Møller, P.; Loft, S. Oxidative stress-induced DNA damage by particulate air pollution. Mutat. Res. 2005, 592, 119-137. [CrossRef] [PubMed]

70. Longhin, E.; Holme, J.A.; Gutzkow, K.B.; Arlt, V.M.; Kucab, J.E.; Camatini, M.; Gualtieri, M. Cell cycle alterations induced by urban $\mathrm{PM}_{2.5}$ in bronchial epithelial cells: Characterization of the process and possible mechanisms involved. Part Fibre Toxicol. 2013, 10, 63. [CrossRef] [PubMed]

71. International Classification of Diseases (ICD) ICD-10 Version. 2016. Available online: http:/ /apps.who.int/ classifications/icd10/browse/2016/en\#/J84.9 (accessed on 16 February 2017).

72. Landrigan, P.J.; Etzel, R.A. Textbook of Children's Environmental Health; Oxford University Press: Oxford, UK, 2013; pp. 1-608, ISBN 9780199929573.

73. Scarlett, J.F.; Abbott, K.J.; Peacock, J.L.; Strachan, D.P.; Anderson, H.R. Acute effects of summer air pollution on respiratory function in primary school children in southern England. Thorax 1996, 51, 1109-1114. [CrossRef] [PubMed]

74. Neuberger, M.; Moshammer, H. Schwebstaub und lungengesundheit-Suspended particulates and lung health (In German). Wien Klin Wochenschr 2004, 116 (Suppl. S1), 8-12. [PubMed]

75. Watanabe, M.; Noma, H.; Kurai, J.; Sano, H.; Hantan, D.; Ueki, M.; Kitano, H.; Shimizu, E. Effects of Short-Term Exposure to Particulate Air Pollutants on the Inflammatory Response and Respiratory Symptoms: A Panel Study in Schoolchildren from Rural Areas of Japan. Int. J. Environ. Res. Public Health 2016, 13, 983. [CrossRef] [PubMed]

76. World Health Organization. Effects of Air Pollution on Children's Health and Development-A Review of the Evidence; WHO Regional Office for Europe: Copenhagen, Demark, 2005; pp. 1-193.

77. He, Q.Q.; Wong, T.W.; Du, L.; Jiang, Z.Q.; Gao, Y.; Qiu, H.; Liu, W.J.; Wu, J.G.; Wong, A.; Yu, T.S. Effects of ambient air pollution on lung function growth in Chinese schoolchildren. Respir. Med. 2010, 104, 1512-1520. [CrossRef] [PubMed]

78. Exposure to Air Pollution (Particulate Matter) in Outdoor Air Copenhagen. Available online: http://www. who.int/ipcs/features/air_pollution.pdf (accessed on 24 April 2017).

79. Oravisjärvi, K.; Rautio, A.; Ruuskanen, J.; Tiittanen, P.; Timonen, K.L. Air pollution and PEF measurements of children in the vicinity of a steel works. Boreal Environ. Res. 2008, 13, 93-102.

80. Rice, M.B.; Rifas-Shiman, S.L.; Litonjua, A.A.; Oken, E.; Gillman, M.W.; Kloog, I.; Luttmann-Gibson, H.; Zanobetti, A.; Coull, B.A.; Schwartz, J.; et al. Lifetime Exposure to Ambient Pollution and Lung Function in Children. Am. J. Respir. Crit. Care Med. 2016, 193, 881-888. [CrossRef] [PubMed]

81. Klepeis, N.E.; Nelson, W.C.; Ott, W.R.; Robinson, J.P.; Tsang, A.M.; Switzer, P.; Behar, J.V.; Hern, S.C.; Engelmann, W.H. The National Human Activity Pattern Survey (NHAPS): A Resource for Assessing Exposure to Environmental Pollutants. J. Exp. Anal. Environ. Epidemol. 2001, 11, 231-252. [CrossRef] [PubMed]

82. Paulin, L.; Hansel, N. Particulate air pollution and impaired lung function. F1000Res 2016, 5, 201. [CrossRef] [PubMed]

83. D'Amato, G.; Vitale, C.; De Martino, A.; Viegi, G.; Lanza, M.; Molino, A.; Sanduzzi, A.; Vatrella, A.; Annesi-Maesano, I.; D'Amato, M. Effects on asthma and respiratory allergy of Climate change and air pollution. Multidiscip. Respir. Med. 2015, 10, 39. [CrossRef] [PubMed]

84. Kumar, R.; Nagar, J.K.; Kumar, H.; Kushwah, A.S.; Meena, M.; Kumar, P.; Raj, N.; Singhal, M.K.; Gaur, S.N. Association of indoor and outdoor air pollutant level with respiratory problems among children in an industrial area of Delhi, India. Arch. Environ. Occup. Health 2007, 62, 75-80. [CrossRef] [PubMed]

85. Siddique, S.; Banerjee, M.; Ray, M.R.; Lahiri, T. Effect of Air Pollution on Incidence of Asthma: A Case Study in Children. Environ. Int. J. Sci. Technol. 2010, 5, 163-175.

86. Barakat-Haddad, C.; Elliott, S.J.; Pengelly, D. Does Chronic Exposure to Air Pollution in Childhood Impact Long-Term Respiratory Health? Prof. Geogr. 2012, 64, 446-463. [CrossRef] 
87. Oluwole, O.; Ana, G.R.; Arinola, G.O.; Wiskel, T.; Falusi, A.G.; Huo, D.; Olopade, O.I.; Olopade, C.O. Effect of stove intervention on household air pollution and the respiratory health of women and children in rural Nigeria. Air Qual. Atmos. Health 2013, 6, 553. [CrossRef]

88. Nunes, R.A.; Branco, P.T.; Alvim-Ferraz, M.C.; Martins, F.G.; Sousa, S.I. Particulate matter in rural and urban nursery schools in Portugal. Environ. Pollut. 2015, 202, 7-16. [CrossRef] [PubMed]

89. Rodriguez, L.A.; Rey, J.J.; Herrera, A.B.; Castro, H.; Niederbacher, J.; Vera, L.M.; Cala, L.L.; Bolívar, F. Respiratory symptoms associated with asthma prevalence and air pollution in preschool children. Biomedica 2010, 30, 15-22. [PubMed]

90. Nandasena, S.; Wickremasinghe, A.R.; Sathiakumar, N. Respiratory health status of children from two different air pollution exposure settings of Sri Lanka: A cross-sectional study. Am. J. Ind. Med. 2012, 55, 1137-1145. [CrossRef] [PubMed]

91. Pedersen, M.; Giorgis-Allemand, L.; Bernard, C.; Aguilera, I.; Andersen, A.M.; Ballester, F.; Beelen, R.M.; Chatzi, L.; Cirach, M.; Danileviciute, A.; et al. Ambient air pollution and low birthweight: A European cohort study (ESCAPE). Lancet Respir. Med. 2013, 1, 695-704. [CrossRef]

92. Gehring, U.; Wijga, A.H.; Brauer, M.; Fischer, P.; de Jongste, J.C.; Kerkhof, M.; Oldenwening, M.; Smit, H.A.; Brunekreef, B. Traffic-related air pollution and the development of asthma and allergies during the first 8 years of life. Am. J. Respir. Crit. Care Med. 2010, 181, 596-603. [CrossRef] [PubMed]

93. Butz, A.M.; Breysse, P.; Rand, C.; Curtin-Brosnan, J.; Eggleston, P.; Diette, G.B.; Williams, D.; Bernert, J.T.; Matsui, E.C. Household smoking behavior: Effects on indoor air quality and health of urban children with asthma. Matern. Child Health J. 2011, 15, 460-468. [CrossRef] [PubMed]

94. Butz, A.M.; Matsui, E.C.; Breysse, P.; Curtin-Brosnan, J.; Eggleston, P.; Diette, G.; Williams, D.; Yuan, J.; Bernert, J.T.; Rand, C. A randomized trial of air cleaners and a health coach to improve indoor air quality for inner-city children with asthma and second-hand smoke exposure. Arch. Pediatr. Adolesc. Med. 2011, 165, 741-748. [CrossRef] [PubMed]

95. Robinson, C.L.; Baumann, L.M.; Romero, K.; Combe, J.M.; Gomez, A.; Gilman, R.H.; Cabrera, L.; Gonzalvez, G.; Hansel, N.N.; Wise, R.A.; et al. Effect of urbanisation on asthma, allergy and airways inflammation in a developing country setting. Thorax 2011, 66, 1051-1057. [CrossRef] [PubMed]

96. Lewin, A.; Buteau, S.; Brand, A.; Kosatsky, T.; Smargiassi, A. Short-term risk of hospitalization for asthma or bronchiolitis in children living near an aluminum smelter. J. Exp. Sci. Environ. Epidemiol. 2013, 23, 474-480. [CrossRef] [PubMed]

97. Madureira, J.; Paciencia, I.; Ramos, E.; Barros, H.; Pereira, C.; Teixeira, J.P.; Fernandes, E.O. Children's Health and indoor air quality in Primary schools and homes in Portugal—Study design. J. Toxicol. Environ. Health A 2015, 78, 915-930. [CrossRef] [PubMed]

98. Lim, H.; Kwon, H.J.; Lim, J.A.; Choi, J.H.; Ha, M.; Hwang, S.S.; Choi, W.J. Short-term Effect of Fine Particulate Matter on Children's Hospital Admissions and Emergency Department Visits for Asthma: A Systematic Review and Meta-analysis. J. Prev. Med. Public Health 2016, 49, 205-219. [CrossRef] [PubMed]

99. Siddique, S.; Ray, M.R.; Lahiri, T. Effects of air pollution on the respiratory health of children: A study in the capital city of India. Air Qual. Atmos. Health 2011, 4, 95-102. [CrossRef]

100. Zora, J.E.; Sarnat, S.E.; Raysoni, A.U.; Johnson, B.A.; Li, W.W.; Greenwald, R.; Holguin, F.; Stock, T.H.; Sarnat, J.A. Associations between urban air pollution and pediatric asthma control in El Paso, Texas. Sci. Total Environ. 2013, 448, 56-65. [CrossRef] [PubMed]

101. Buonanno, G.; Marks, G.B.; Morawska, L. Health effects of daily airborne particle dose in children: Direct association between personal dose and respiratory health effects. Environ. Pollut. 2013, 180, 246-250. [CrossRef] [PubMed]

102. Ferreira, A.; Cardoso, S.M. Effects of indoor air quality on respiratory function of children in the 1st cycle of basic education of Coimbra, Portugal. Occup. Saf. Hyg. II 2014, 2014, 347-350.

103. Ramesh, B.Y.; Manjunath, N.; Sanjay, D.; Dhanya, Y. Association of indoor air pollution with acute lower respiratory tract infections in children under 5 years of age. Paediatr. Int. Child Health 2012, 32, 132-135. [CrossRef] [PubMed]

104. Sram, R.J.; Binkova, B.; Dostal, M.; Merkerova-Dostalova, M.; Libalova, H.; Milcova, A.; Rossner, P., Jr.; Rossnerova, A.; Schmuczerova, J.; Svecova, V.; et al. Health impact of air pollution to children. Int. J. Hyg. Environ. Health 2013, 216, 533-540. [CrossRef] [PubMed] 
105. Marchettia, P.; Marcona, A.; Pesce, G.; Paolo, G.; Guarda, L.; Pironi, V.; Fracasso, M.E.; Ricci, P.; de Marco, R. Children living near chipboard and wood industries are at an increased risk of hospitalization for respiratory diseases: A prospective study. Int. J. Hyg. Environ. Health 2014, 217, 95-101. [CrossRef] [PubMed]

106. Zhang, X.; Li, F.; Zhang, L.; Zhao, Z.; Norback, D. A longitudinal study of sick building syndrome (SBS) among pupils in relation to $\mathrm{SO}_{2}, \mathrm{NO}_{2}, \mathrm{O}_{3}$ and $\mathrm{PM}_{10}$ in schools in China. PLoS ONE 2014, 9, e112933. [CrossRef] [PubMed]

107. Zhang, Y.; Li, M.; Bravo, M.A.; Jin, L.; Nori-Sarma, A.; Xu, Y.; Guan, D.; Wang, C.; Chen, M.; Wang, X.; et al. Air quality in Lanzhou, a major industrial city in China: Characteristics of air pollution and review of existing evidence from air pollution and health studies. Water Air Soil Pollut. 2014, 225, 2187. [CrossRef] [PubMed]

108. Kumar, R.; Nagar, J.K.; Kumar, H.; Kushwah, A.S.; Meena, M.; Kumar, P.; Raj, N.; Singhal, M.K.; Gaur, S.N. Indoor air pollution and respiratory function of children in Ashok Vihar, Delhi: An exposure-response study. Asia Pac. J. Public Health 2008, 20, 36-48. [CrossRef] [PubMed]

109. Neuberger, M.; Moshammer, H.; Schietz, A. Exposure to ultrafine particles in hospitality venues with partial smoking bans. J. Exp. Sci. Environ. Epidemiol. 2013, 23, 519-524. [CrossRef] [PubMed]

110. Mahr, T.; Makka, J.; Spahn, J. Inflammometry in pediatric asthma: A review of fractional exhaled nitric oxide in clinical practice. Allergy Asthma Proc. 2013, 3, 210-219. [CrossRef] [PubMed]

111. Poulose, V. Usefulness of FeNO in the Diagnosis of Chronic Cough. Chest 2014, 145 (Suppl. S3), 567A. [CrossRef]

112. Effects of Air Pollution on Children's Health and Development-A Review of the Evidence. Available online: http:/ / www.euro.who.int/_data/assets/pdf_file/0010/74728/E86575.pdf (accessed on 16 February 2017).

113. Lakhani, N.; North, M.; Ellis, A.K. Clinical Manifestations of Allergic Rhinitis. J. Allergy Ther. 2012, S5, 7. [CrossRef]

114. Spann, K.; Snape, N.; Baturcam, E.; Fantino, E. The Impact of Early-Life Exposure to Airborne Environmental Insults on the Function of the Airway Epithelium in Asthma. Ann. Glob. Health 2016, 82, 28-40. [CrossRef] [PubMed]

115. Baraldi, E.; Carraro, S.; Filippone, M. Bronchopulmonary dysplasia: Definitions and long-term respiratory outcome. Early Hum. Dev. 2009, 85 (Suppl. S10), S1-S3. [CrossRef] [PubMed]

116. Harrison, R.M.; Yin, J. Particulate Matter in the Atmosphere: Which Particle Properties are Important for its Effects on Health? Sci. Total Environ. 2000, 249, 85-101. [CrossRef]

117. Valet, R.S.; Gebretsadik, T.; Carroll, K.N.; Wu, P.; Dupont, W.D.; Mitchel, E.F.; Hartert, T.V. High asthma prevalence and increased morbidity among rural children in a Medicaid cohort. Ann. Allergy Asthma Immunol. 2011, 106, 467-473. [CrossRef] [PubMed]

118. Gehring, U.; Gruzieva, O.; Agius, R.M.; Beelen, R.; Custovic, A.; Cyrys, J.; Eeftens, M.; Flexeder, C.; Fuertes, E.; Heinrich, J.; et al. Air pollution exposure and lung function in children: The ESCAPE project. Environ. Health Perspect. 2013, 121, 1357-1364. [CrossRef] [PubMed]

119. Mölter, A.; Simpson, A.; Berdel, D.; Brunekreef, B.; Custovic, A.; Cyrys, J.; de Jongste, J.; de Vocht, F.; Fuertes, E.; Gehring, U.; et al. A multicentre study of air pollution exposure and childhood asthma prevalence: The ESCAPE project. Eur. Respir. J. 2015, 45, 610-624. [CrossRef] [PubMed]

(C) 2018 by the authors. Licensee MDPI, Basel, Switzerland. This article is an open access article distributed under the terms and conditions of the Creative Commons Attribution (CC BY) license (http://creativecommons.org/licenses/by/4.0/). 